\title{
A study on soft skill training as an intervention to reinforce employee performance in the contemporary banking sector
}

\author{
Sanjay K Deshpande ${ }^{1}$, M . M. Munshi ${ }^{2}$ \\ \{sanjaydeshpandegit@gmail.com ${ }^{1}$, mmmunshi@rediffmail.com² \\ Visvervaraya Technological University VTU, Macche, Belagavi, Karnataka ${ }^{1,2}$
}

\begin{abstract}
In 20th century soft skills are a major differentiator, a sine qua non for employability and success, Heckman and Kautz (2012) [1] , the case of banking sector covering about 1, 49,163 branches of commercial banks in India is akin to this. There has been an increased focus on soft skills to hone leadership capabilities, enhance knowledge of rules and regulations of the industry (RBI report 2014) [2]. This research study strives to illustrate the role of soft skill training in reinforcing the employee performance in banking sector, and is a blend of empirical and conceptual research relying on the data from authentic sources. It was conducted in the city of Belagavi of Karnataka state to know whether soft skill training imparted to employees of banks at staff training colleges and other nodal bodies like NIBM can reinforce employee performance. Data analysis was done using statistical tests like regression, Anova in SPSS software.
\end{abstract}

Keywords: Soft Skills Training, Employee Performance, Banking sector.

\section{Introduction}

Alike any other sector banking sector in India has undergone a massive change, for instance from traditional banking to mass banking to digital and customized banking. The basic reason behind this transformation is the change in needs and preferences of customers and percolation of technology in all facets of life. A report of Reserve Bank of India (RBI) says, India's banking sector is effectively structured, well-regulated and organized. The financial and economic activities are much superior to other countries. Indian banking sector has recently witnessed the rollout of many innovative banking models. RBI's new initiatives will pave the way in assisting restructuring of the domestic banking sector [2]. Banking sector of India system is comprised of 27 public sector banks, 22 private sector banks, 44 foreign banks, 56 regional rural banks, 1,589 urban cooperative banks and 93,550 rural cooperative banks, besides many cooperative credit institutions [3]. The banking sector is the lifeline of a developing country like India and also a platform on which nationwide ambition of financial inclusion is based on. The state of Karnataka, Dakshin Kannada, in particular, is said to be the cradle of the modern banking industry in India, as it is the place of origin for many nationalized banks to name a few are Syndicate Bank, Corporation Bank, Vijaya Bank, Karnataka Bank, Canara Bank Vysya Bank, State bank of Mysore. Besides its rich cultural history, Karnataka also has the rich scope of trade and commerce. Banking sector plays an essential role to enhance the economic growth of India. To augment output and efficacy, banks should have higher flexibility in operations, particularly in HR processes and operations [4]. Achieving higher productivity and efficiency requires a fine blend of right technology, systems, and operations, besides right skills and attitude of employees, exhibiting higher flexibility and adaptability are inevitable to keep pace with the changing times. The report of the Banking Commission observed, "As the crucial role of training in fulfilling the objectives of developmental banking was not adequately realized in the Indian banking sphere, there has been a backlog in the provision of training facilities [5]. New dimensions added to the banking objective recently have further accentuated the need for expanding the scope and improving the quality of training and for the formulation of integrated training programmes." Thereby training has assumed a significant role in supplementing the efforts of the bank personnel in meeting the new work demands arising out of the growth and expansion of the banking system. In this development, many nationalized banks have set up their own training colleges and in some instances, two or more banks joined together and set up a combined training college to achieve economies of scale. For instance, Bank of Baroda set up a training college jointly with Bank of India. Need and demand for better customer service in service sector has escalated than ever before in service sector in general and banking in particular. Bank account portability, demand real time and faster services , need for customized services (personalized banking), Net banking, customer retention are the areas that banks today are grappled with, any apathy and disregard in the above mentioned interalia educating customers about new products, cut throat competition could drastically pull down the performance of the bank. Hence the bank staff is expected to be equip with right mix of skills in order to provide best services. Since services sector for 
instance banks delve predominantly on communication/ interaction with customers. The way of communication could either make or break business operations for banks. Realising the importance of this, RBI has made it mandatory to all banks to impart soft skills training to their staff. It is also noteworthy to mention that customer expectations, customer diversity are also increasing because ambit of banking is also increasing due to programs like financial inclusion [6].

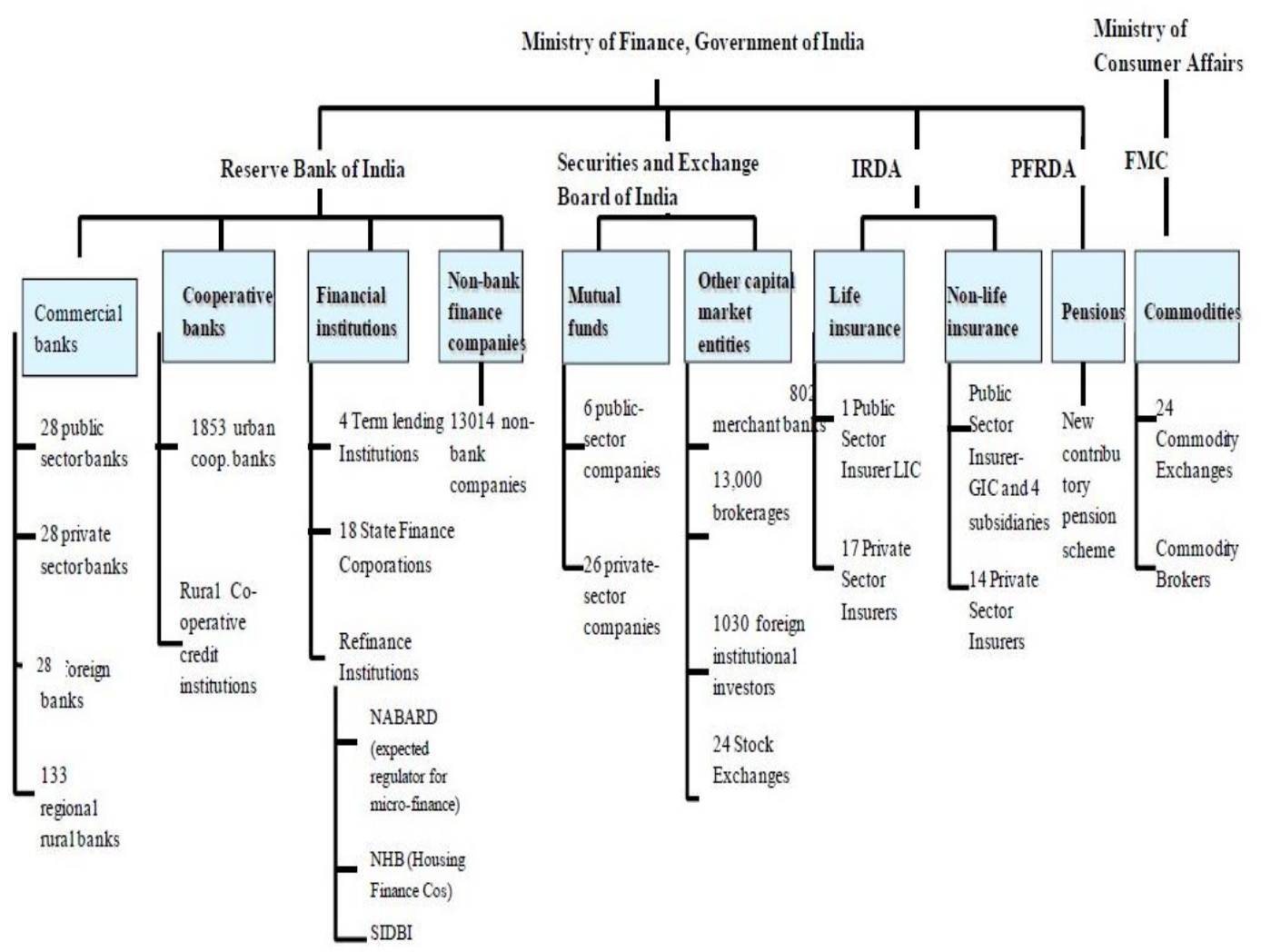

Figure 1. A snapshot of a financial system of India

Source: Human Resource and Skill Requirements in the Banking Financial Services \& Insurance Sector(2022) a report. [7]

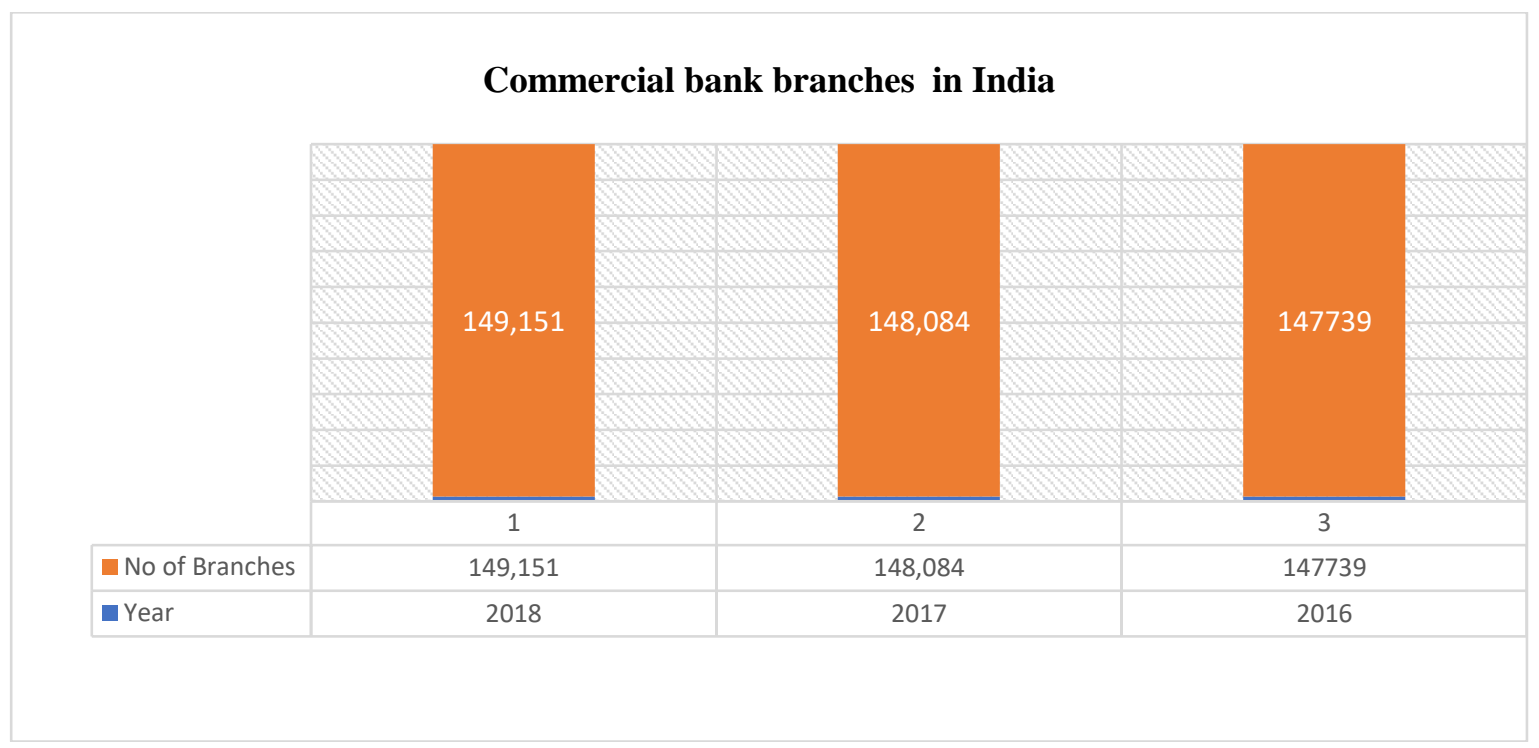

Figure 2. No of commercial bank branches in India Source: Branch banking statistics, Jun 18 RBI [2] 


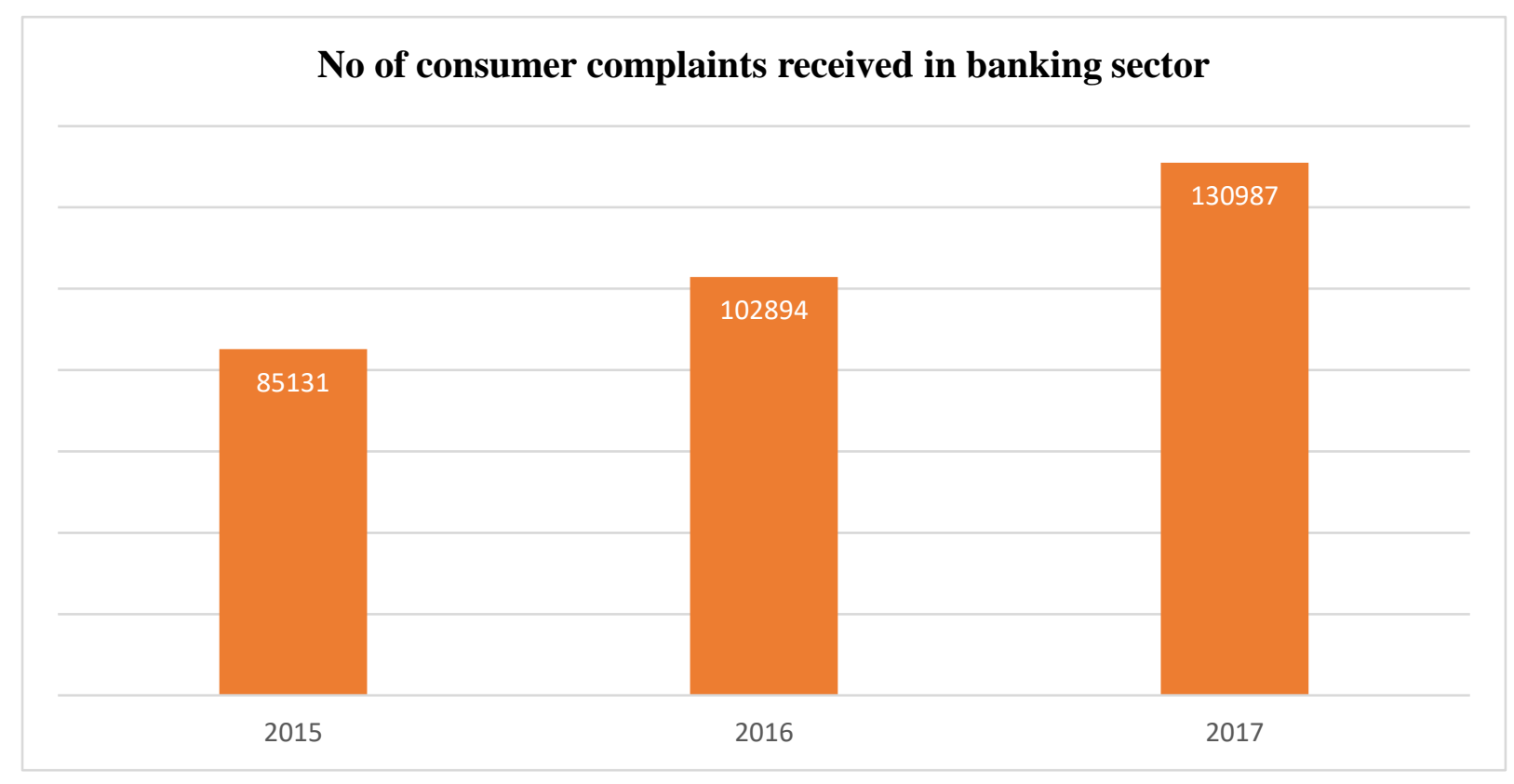

Figure 3. Indicates that a number of consumer complaints are on the rise over the last three years $(2016,2017,2018$, in banking sector accentuating the need to reduce them, since banking being a service firm, service provided by the employees becomes the defining factor. Employee's behaviour can be modulated by providing soft skills training. Source: Consumer Protection in the Banking Sector, [8]

\subsection{Objectives of the study}

1. To understand the impact of soft skills training on employee development.

2. To determine whether employee performance is dependent on soft skill training.

\subsection{Research Problem}

The most popular model for training evaluation is the Kirkpatrick Model can be used to evaluate. The 4 levels of evaluation in the model are Reaction, Learning, Behaviour, and Results. Hitherto, many global organizations and researchers have struggled training programs to meaningfully go beyond the second level viz. learning [2]. A very microscopic number of researchers have experimented with Behaviour level. There is not much credible evidence on the measurement of results viz ROL. Hence, detailed research needs to be undertaken in this regard (RBI report, 2014). A partial attempt has been made in this research to evaluate the training program by developing a data collection instrument (survey instrument).

\subsection{Scope of the study}

Present study is undertaken in the city of Belagavi, Karnataka State employees of private and public sector bank have been interviewed using a structured questionnaire, to ascertain whether soft skills training imparted to them has reinforced the performance.

\subsection{Why Belagavi city of Karnataka was chosen?}

Belagavi being listed as a smart city in the first phase of Govt of India in 2016. As of 2008-09, Belgaum district had the second largest Gross District Domestic Product (GDDP) in Karnataka at Rs 16,495.89 crore. The district economy is pre-dominantly service based, with service sector's share in GDDP at 48 per cent in 2008-09 followed by secondary sector at 30 per cent and primary sector at 22 per cent (NSDC REPORT 2013) has been chosen as the scope of the study. As per census 2011, the population of Belagavi was 4,88,157 lakhs with 3, 91,341 lakh literates, which accounts to literacy ratio of $80 \%$, consider the above facts Belagavi city is feasible and potential enough to take up a research study. 


\subsection{Significance of the study}

Training term per se sounds age old and familiar, etched even on a layman's mind as a process where people are taught something, however, we all should be apprised about mutations it has undergone owing to an array of reasons, changing business trends have influenced the way people are trained today, the word training is gradually getting replaced with the much touted learning . Video training, online training, tele-training, social network interface training etc, are the buzzing trends, the changing scenario of these various methods may be attributed to a host of factors namely IT revolution, changing economic conditions market conditions, globalization, privatization etc. Today MNCs are typically characterized by a paucity of time and expect the new incumbents to hit the ground running, produce impulsive and palpable results; hence the desire of top management to save training expenditure on imparting basic skills also influences the recruitment approach of the company. The emphasis today is on time and cost for training and its correlation with the impact of training. ROI (Return on Investment) on training has become an inevitable issue to contemplate upon [9], owing to a bag full of reasons like reducing profit margins, ever changing customer demands and choices, declining customer loyalty, cut throat competition, employee attrition etc. hence the top management / CEOs are circumspect to invest huge money on training, which makes them apprehensive about the outcome of training being against their favour [9]. Outsourcing a training function in various domains is seeing frequent hopping from one service provider to the other, reasons for this being ROI and impact of training. This study also contributes to how soft skills and its dimensions are related to each of the dimensions of work performance namely, customer service, team work. The study findings will give more inputs to organizations and will put them in , training and development programs, designing performance appraisal, promotion decisions etc. The research findings might also have implications for training managers to modulate modus operandi of training and improve efficiency. This research will also make contributions to the existing body of soft skills literature and knowledge.

\subsection{Rationale behind the study}

The study is conducted to know whether soft skills training imparted to the employees of the banking sector after joining can be intervention to reinforce the employee performance.

\subsection{Need for Training}

According to Uday Pareek \& Rolf Lynton in a book titled "Training for organizational Transformation", Training needs across sectors and organizations triggers because of three crucial reasons [9].

a. Outwardly changes in the business scenario, situations \& styles.

b. Making up for deficiencies and shortfalls to ensure the firm does not lag behind and is able well spruced up to face competition.

c. Overcome cultural differences, educational backgrounds

\subsection{Conceptual framework for study}




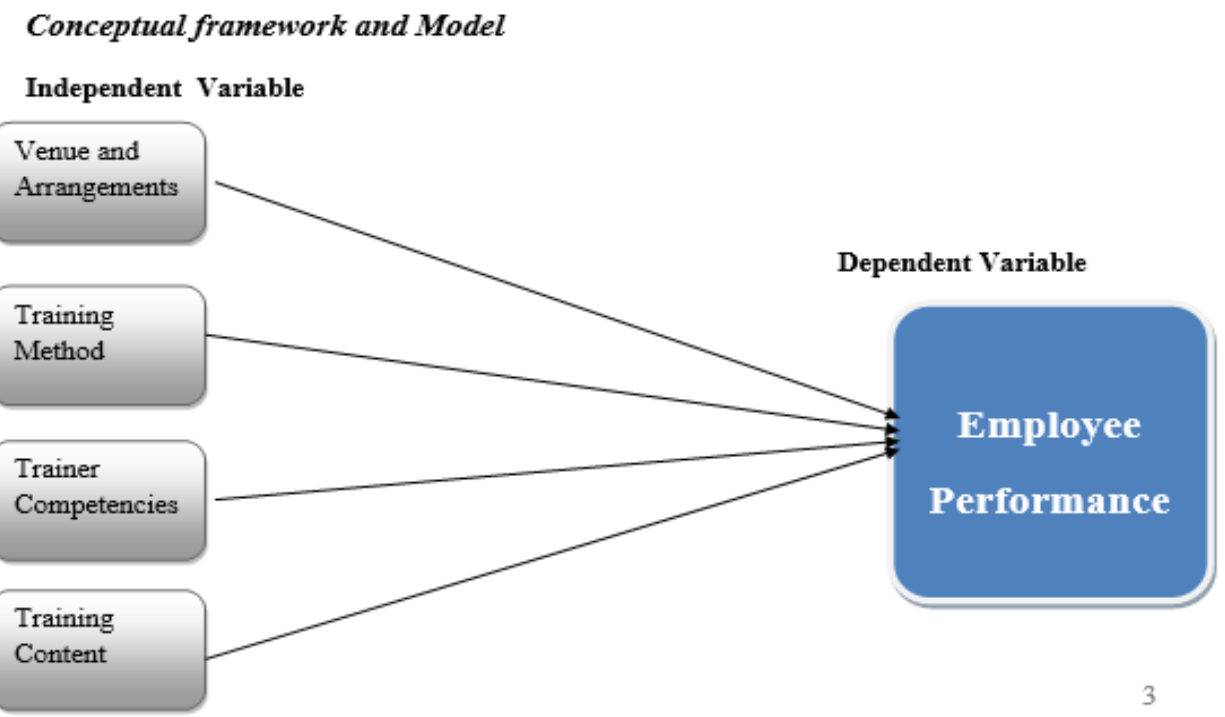

Figure 4. Conceptual framework and model

Source: IUP journal of soft skills, Spetember 2014 [10]

\subsection{Research Methodology}

This research study is descriptive in nature design, it is a quantitative study which aims to find out if an independent variable i.e. "Soft skill training can influence a dependent variable "Employee performance". Questionnaires were administered on the employees of banks working in the city of Belagavi.

- Sampling Method: Convenience Sampling

- Sample Size: 65

- Sampling Frame: Employees of the Banking Sector (Private and Public Sector Units).

- Sampling unit: City of Belagavi, Karnataka State, India

- Statistical Tools Used: Cronbach's Alpha Validity Test, Anova, Regression.

\subsubsection{Scaling Techniques used for data collection}

Non-comparative scaling technique was used in the questionnaire. Variables which are perception based were measured on 5-point Likert's scales with end points of "strongly disagree" and "strongly agree". For the purpose of primary data collection through survey research, employees of banks were asked to rate the extent to which they agree or disagree.

\subsubsection{Developing Data Collection Instrument (Questionnaire)}

A data collection instrument was constructed and employed to measure the impact of a soft skills training program on the performance of employees of service firms. Specific need to obtain a validated questionnaire as well as insuring that the questions accomplish the research objectives. The review of literature indicates that soft skills training contributes to interpersonal development and thereby perform better at the job, Observational insights gained interaction with managers and subject matter experts during the pilot indicate that training evaluation is done by internally developed mechanisms is mostly done for internal analysis by their learning and development This data collection instrument (Questionnaire) had 3 sections in it namely section a , b and c. Section a contains 6 items on About training, section b contains About the Instructors / Facilitators/ Trainers: section c contains 6 items on Impact evaluation, In all the questionnaire, had 18 items in it, content validity for the questionnaire is mentioned in table 1 below, and the instrument is furnished as annexure. 
Table 1. Content validity of the questionnaire [10].

\begin{tabular}{|l|l|l|}
\hline Variable & Application in the instrument & Source \\
\hline Venue & Plays a vital role, influence, learning & $\begin{array}{l}\text { Training and Development, G. pandu } \\
\text { Naik 2010 [10]. }\end{array}$ \\
\hline Well designed & Contents of training & $\begin{array}{l}\text { Training and Development Bhatia S K } \\
\text { 2008[9]. }\end{array}$ \\
\hline Corporate standards & $\begin{array}{l}\text { Soft skills training helps corporate } \\
\text { grooming. }\end{array}$ & Philips software Centre[10]. \\
\hline Competencies of the trainer & $\begin{array}{l}\text { Trainers demonstrated knowledge of the } \\
\text { subject with confidence }\end{array}$ & Dawn 2004 [10]. \\
\hline
\end{tabular}

\subsubsection{Determination of sample size}

Referring to the data of branch banking statistics published by RBI i.e District wise number of functioning offices of commercial banks at the end of quarter September 2018641 branches functioned in Belagavi District of Karnataka state. Since the standard deviation of the population was unknown, random sampling method was used for data collection, and validity purposes using $10 \%$ rule of sampling 60 samples (large sample since more than 30) were collected for analysis.

\subsection{Glimpse of Future Job skills}

Banking and insurance will face one of the most pervasive workforce transitions in the years to come. Jobs such as tellers, financial analysts, and brokerage clerks will wane substantially, while the number of technology professionals and customer interfacing Roles will grow [11]. The need for workers who practice, monotonous basic cognitive skills, such as data input and processing and basic literacy and numeracy, will likely decline, while the need for workers with advanced technology skills, and those with social and emotional skills, will grow. Birth of contemporary competitors aspiring to capitalize on the unbanked and encourage the project of financial inclusion [11]. Payments Banks (PBs) a contemporary concept is implemented to reform the conventional banking system and sector. India predominantly being a cash-based economy needs to embrace digital payment instruments escalate cashless payments. Payments Banks will have long term consequences in the way large financial institutions function, leveraging innovations in "Financial Technology" is the way forward to lower the transactional costs by embellishing the value chain. Changing market trends have modified the traditional money cycle[12]. Inherent issues such as Information Technology, cyber issues, and infrastructure preventing traditional banks to adapt to the latest developments, are not the hindrances to PBs, their agility makes them different than traditional banks[12]. The RBI has issued license payment banks to many telecom companies and mobile wallet operators with a view to bringing them under the banking ambit. GOI, Govt of India, expects these PBs to reinforce its campaigns like "Pradhan Mantri Jan Dhan Yojana", "Aadhaar Act", and "Digital India". Traditional banks may not be so agile and flexible to provide these facilities [12].

\subsection{Literature Survey}

Whitemore Paul G (1972) Soft skill term per se was used for the first time used in 1972 and was not very popular until the early 1990s. Soft skills are important job-related skills that involve little or no interaction with machines whose application on the job cannot be ignored skills in the context of organizational working and success[13].Harrison (1993) in his research mentioned that training and development is the field which is concerned with organizational activity aimed at bettering the performance of individuals[14] Moss and Tilly define soft skills as "skills, abilities, and traits that pertain to personality, attitudes, and behavior rather than to formal or technical knowledge"[15]. Bernardin \& Russell (1998), have defined training as an attempt to increase employee performance on a current job or the one related to it. This usually means necessary and expected changes in specific knowledge, skills, attitudes. of soft skills acquisition and the training methodology adopted on the performance of employees is very significant[16]. Watts and Watts, 2008 hard skills contribute to only $15 \%$ of one's success, while the remaining $85 \%$ is contributed by soft skills. Jessy, 2009 stated that besides formal, professional qualification and domain knowledge, today's professionals 
need to possess high soft skills quotient in order to succeed in this competitive era. Hence soft skills pave way for sustenance in the journey[17].Heckman and Kautz (2012) in the 20th century soft skills are a major differentiator, a sine qua non for employability and success in life. A study conducted by Harvard University noted that $80 \%$ of achievements in career are determined by soft skills and only $20 \%$ by hard skills. Hence are vital [1]. Ibrahim, Rosli; Boerhannoeddin, Ali; Bakare, Kazeem Kayode (2014) in their research paper titled "The effect of soft skills and training methodology on employee performance that soft skill training performance enhance employee performance, and consequently, organizational performance, further it also found out that soft skill training consisting of ingredients like leadership skills, ability work in teams, creativity, communication skills and problem-solving imparted by the trainer had a positive impact on the employees, they assessed the interrelationship between the acquisition of soft skills by employees, training methodology adopted by the trainer, and work performance. The results specify that the two predictors' acquisition of soft skills and training methodology meaningfully predict employee performance. This research study indicates 14.5 percent increased employee work performance in the selected companies because of their employees' acquisition of soft skills [18].An RBI report of 2014 says contemporary times requires a fine and proportional blend of attitude, behavioural and technological training, coupled with knowledge inputs to cater to the areas, customer service being paramount of all. With an increasing number of banks and financial Institutions venturing into tele-calling mode, hence soft skills have become as imperative as conventional skills and expertise. Careful and systematic evaluation of training programs is crucial to know training and ROL (Return on Learning).There is not much credible evidence on the measurement of results viz ROL. Hence, detailed research needs to be undertaken in this regard [19]. Charoensap-Kelly, P., Broussard, L., Lindsly, M., \& Troy, M. (2016). In their research titled "Evaluation of a Soft Skills Training Program" stated that training is an effective tool to teach employees how to "mould" their personal traits and styles to improve their relationships with one and all (coworkers). Professional communication training imparted reported the behavioural change and positive business implications. The training aims to foster employee learning and performance [20].Amitabh Deo Kodwani in his research study "Decoding training effectiveness" (2017) the role of organizational factors" found out that training environment, training awareness, participation and involvement in training, training assessment mechanism were found to be positively related to perceived training transfer. Transfer her refers to the transmission of knowledge from trainer to trainee [21]. Omar, A., Salessi, S., \& Urteaga, F. (2017) in their study stated that the type of human resource management is of crucial importance regarding the development of attitudes related to work, such as job satisfaction. Job satisfaction is a desirable outcome of many initiatives and processes of the firm[22]. Ashita Bhagra and Dinesh Kumar Sharma (2018) in their study concluded that today technological innovations are affecting the skills requirements at the job like never before. Re-skilling and up-skilling are becoming keywords to gaining and retaining in a job. Organizations are increasingly using competency mapping for talent acquisition to maintain the right size for sustainability. The holistic view of employability skills includes personal attributes, workplace skills, applied knowledge skills, and core knowledge skills influencing personal, academic and professional performance in the corporate environment. Reskilling helps to overcome skill obsolesce of staff [23].

\subsection{Training Intervention in banks}

Training function is often referred to as capacity building in the context of banking. A Committee to building capacity in banks and NBFCS in India was constituted by RBI to enable capacity building in banks and NBFCs, training was regarded as an important intervention to withstand and meet the ever-increasing challenges in banking and financial sector; many incentives based certification based programs were introduced across all hierarchical levels from lowest ranked employee to top notch board level staff to facilitate learn new skills / skill advancement. These training programs were further subjected to tests and monitored through examinations conducted on trainees. With the complexity rising in banking and financial sector training programs were imparted with the stark need to boost the economy and enable growth of the same. Capacity building programs were given paramount importance to propel the growth trajectory. Intellectual capital being the vital factor in the service sector which includes the banking sector, it is an imperative need that various endeavors having the capacity building as a mandate should be considered and executed to complement capacity needed for present and the future scenario[24]. The realm of the committee is profoundly is to provide training and consider training as an important intervention required to improve the worth and productivity of banking staff employed across several levels in banks and NBFCs regulated by the RBI. Many NBFCs controlled and administered by RBI become an integral part of this measure, to get the skill base of their employees enhanced and raise the current bar [24]. 


\subsection{Essential recommendations of the committee on the Training process}

This Committee was of the opinion that examination at the entry level of knowledge, skills, and attitude in employees across streams facilitates designing of developing better capacity building programs. Committee also further recommended the following six steps for skill development initiatives / Process [24].

I. Identify Business and learning objectives for the year - The process of skill development begins with a primary focus on the following question- "what are the specific areas of operations in the organization which need to be developed and how to reduce the skill gap?" Before submitting the skill development plan, the important aspect to know whether the bank needs to developed[24] .

II. Sourcing the requirements of Training - Once requirements for skill development are identified, the next stage is to know whether people match the role assigned to them and further identify their development requirements if found, any. This particular identification can be done through skill mapping[24].

Recommended sourcing - supervisor or committee for talent review recommends a particular employee for a specific training program based on skill mapping. Sourcing can be also done by analyzing the performance records of employees; [24].

Self-assessment - It is a process where employees offer their nomination through an online portal on based the self-realized need for training or skill development. Following the above mentioned methods sourcing is executed, hence the group of trainees is identified for whom training is to be imparted [24].

III. Adopting 70:20:10 learning model - This is a contemporary method that is followed the world over. 70:20:10 learning model is an exceptional learning model and considers the parameters like experience, feedback, and formal training. It relies on andragogy (adult learning), it believes that maximum learning happens through experiences (70\%) followed by feedback (30\%) and formal training (10\%) Thus, major emphasis should be on job related exercises, for instance through projects, field work etc[24].

IV. Preparation of training schedule -Well planned training schedule will ensure that employees have minimum ambiguity about their future career path and its associated learning curve - here a meticulous schedule containing the training objectives, Trainees list , Training methods in congruence with 70:20:10 learning model is prepared. This list and individual intimation letters are published and communicated to trainees and immediate managers at the commencement of the year, so that employees clearly and prepared mentally, accessible at the said time in the schedule, immediate managers will also ensure work allocation and deputation [24].

V. Observation through tests and talent review - This process involves monitoring whether the training program is delivered as per the plan and has really proved beneficial for the organization and has it given a return for the employee and organization as well. Some of the ways to measure the effectiveness of training programs are as under:

a. Conduct of tests (Certification) - An annual test may be conducted to measure the development in the knowledge level of employees who underwent training in a relevant stream. Employees are expected to pass a certification program to progress to the next grade[24].

b. Talent review - Talent review committee will track whether the employee has benefitted or has shown improvement as a result of the training administered, this is be done by conducting interviews or viva sessions.

VI. Rewarding / Encourage Learning - To enhance learning attitude in the bank, there must a good synchronization reward \& recognition programs and learning. For instance, incumbents/ trainees who successfully clear certification programs should be given priority during the promotion. Incentives should aim to promote better learning. A center for leadership development can be started and people who continuously perform and learn can become members of the center. A pool of top 100 or 200 can be groomed to become potential future leaders of the bank. This data pool can be used harnessed in many numbers of ways. For instance, employees who score higher grades or marks in the tests/assessments can be offered choice placements or awards that will benefit them to advance themselves as domain/ stream/ area experts in the field[24]. 


\subsection{Training perspective at large}

Training term per se sounds age old and familiar, etched even on a layman's mind as a process where people are taught something, however, we all should be apprised about mutations it has undergone owing to an array of reasons, changing business trends have influenced the way people are trained today, the word training is gradually getting replaced with the much touted learning, to feel the impact factor. Video training, online training, tele-training, social network interface training etc, are the buzzing trends, the changing scenario of these various methods may be attributed to a host of factors namely IT revolution, changing economic conditions market conditions, globalization, privatization etc. Today MNCs are typically characterized by a paucity of time and expect the new incumbents to hit the ground running, produce impulsive and palpable results; hence the desire of top management to save training expenditure on imparting basic skills also influences the recruitment approach of the company. The emphasis today is on time and cost for training and its correlation with the impact of training. ROI (Return on Investment) on training has become an inevitable issue to contemplate upon [10], owing to a bag full of reasons like reducing profit margins, ever changing customer demands and choices, declining customer loyalty, cut throat competition, employee attrition etc. hence the top management / CEOs are circumspect to invest huge money on training, which makes them apprehensive about the outcome of training being against their favour. Outsourcing a training function in various domains is seeing frequent hopping from one service provider to the other, reasons for this being ROI and impact of training. The foremost concern in the 21 st century has shifted from improving individuals to contributing to better functioning of organization and enhancing its skill sets to combat the changing business climate and enjoy a competitive edge over the rest of business players[10], from the host of the training methods, every training manager expects a better outcome depicted through increased performance and decreased errors. Harnessing the potential benefits of a training function is the need of the day.

\subsubsection{Training from Trainees Perspective}

Having deputed to attend the training program, trainees experience with regard to the training program is a mixed bag. A few realize that, it could well be a springboard for success and it is vital to implement the learning of the same on to their respective roles in order to grow, sustain and compete, cope up with the mutations in the business climate, while others take it as an opportunity to get treated in a royal way, and feel its pleasure time, an avenue to destress, A few smart corporate executives leverage the most out of the training program by blending both the above mentioned ways.

\subsubsection{Training from Company's Perspective}

Corporate world today is embracing much valued "High Leverage Training (HLT)" HLT constitutes of equipping employees with basic skills, advanced skills, Product knowledge, Customer Behaviors skills[10], these components are eventually linked with strategic business goals, thereby clarifying the goals of an organization \& employees and ensure mutual compatibility. It further believes in having a holistic approach. Many training programs taken up at scores of companies have proved futile and have also failed to fulfill the intended objectives, the possible reasons for the same could be faulty designing of the program, improper evaluation, non-aligned to strategic objectives of the organization. Training programs conducted across the sectors/ industries should strive to make the trainees learn crucial job related competencies categorized under various heads like verbal information, attitude transformation, cognitive skills, intellectual skills \& motor skills[10].

\subsubsection{Training from the Trainer's Perspective}

The trainer is like a captain of the ship and is expected to direct the organization, imbibe critical skills to the trainees and make the ship called the organization to reach a safe shore from rough weathers and troubled waters. However many times the trainer is inhibited by many bottlenecks like financial issues, the apathy of the top management, and lack of zeal amongst the trainees. One of the constraints faced of late by trainers and training function per se in tier II and III cities is the reluctance on the part of top management \& key stakeholders to pursue and incorporate it into their organizations, the reason for which is a mystery to be unraveled upon, sheer analysis of the same would enhance the appetite \& enthuse a training consultant / trainer.

\subsubsection{Training Evaluation}

To ensure training efficiency in the organization, it is recommended to have an evaluation mechanism in place. Donald Kirkpatrick, An American practitioner, and training consultant provides valuable insights about the evaluation through his "Evaluation Training Model". Patrick's model is based on four parameters as 
mentioned below. Figure 5 represents the levels of kirk patrick's training evaluation model [25].

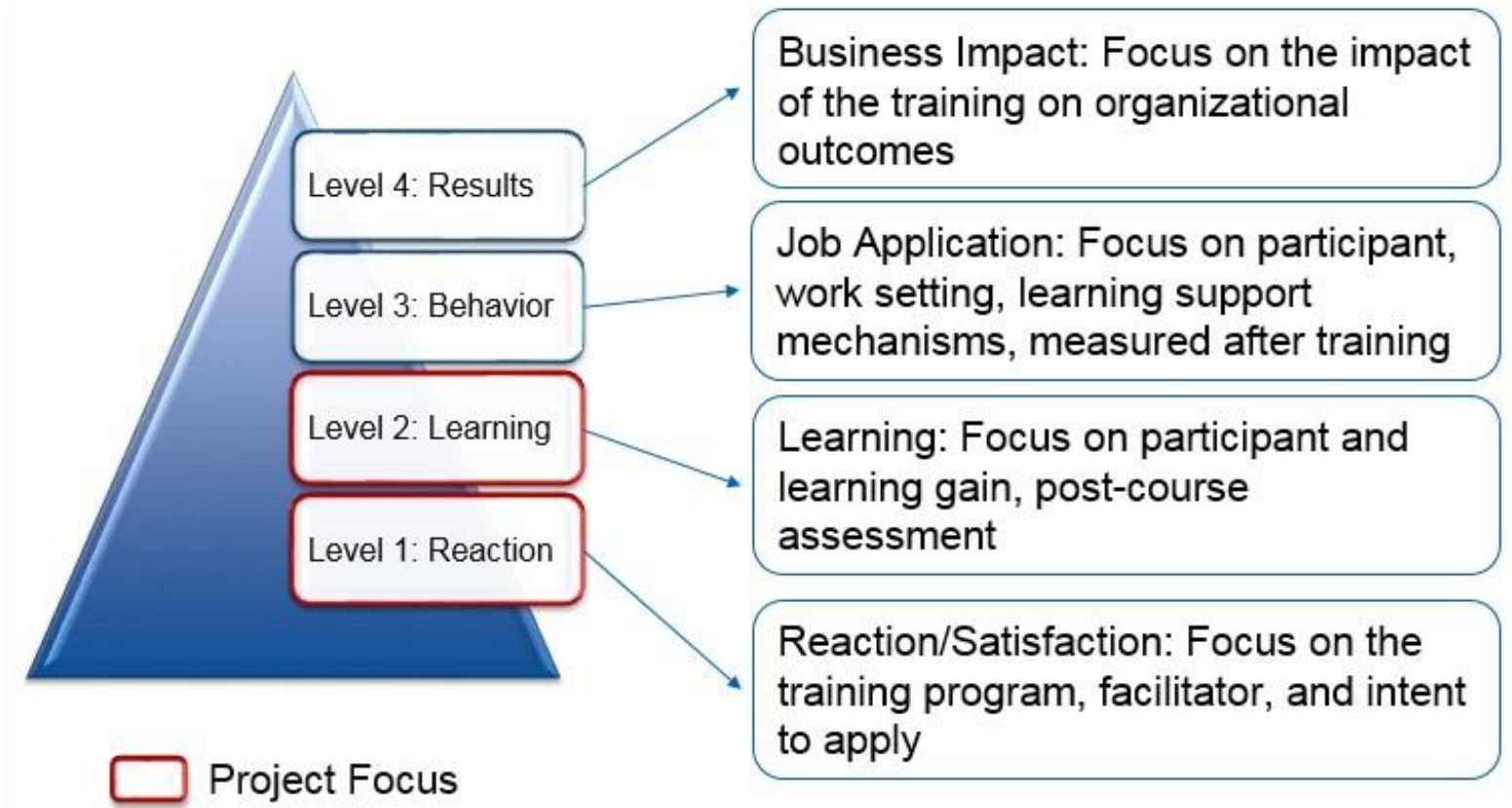

Figure 5.

Source : Clarence Dillon[25]

\subsection{Soft skills Training in banks}

Soft skills training in banks is referred to as nonfunctional training, there has been a thoughtful emphasis on the development of "soft skills" besides extra skill sets[2]. Furthermore, a well prepared blend of classroom teaching and coaching on the job i.e "OJT" (on the job training) is considered to be the most suitable form of training in banks for their staff members. Efforts to develop skills on the job and the ability to apply them to everyday situations in the course of discharging duties is given prime importance. Classically, any program that aims to enhance talent base of employees has to necessarily understand the prospective trainees work profile, specific talents, and skills and the level of expertise they have gained in the work area assigned to them. Hence there is a strong need to contemplate a path to upgrading skill-sets, knowledge and attitude, all at the same time. Thus, training of employees across all echelons of the organisation can play a significant role in enhancing what is known as "KASH"-Knowledge, Attitude, Skill, and Habits [2].

\subsection{Types of training provided to employees}

\section{Compliance Training}

Considering the regulations issued by RBI, it is enviable both for banks and financial services organizations to comply and abide with and by stipulations of the regulatory bodies. Hence compliances mechanisms are must to impart through training to bank employees. Example: (KYC norms) [26].

\section{Process Training}

Operations, Processes involve a series of steps and sequences to be executed, this involves training of various processes in handling banking functions or specific financial services delivery. Example Loan approval disbursement [26].

\section{Application Software Training}

With technology percolation and core banking being the platform on which the banking sector thrives, financial software applications are the foundation for both Banking and Financial Services, and the training on these for the employees is unavoidable [26] .

\section{Sales Training}


With diversification becoming a live without strategy and product folio getting bigger and wider, products, Services and solutions training is also considered important to achieve the following objectives [26].

- To differentiate from competitors products and services.

- To prevent the interlacing effect from existing products and services.

\section{Soft skill training}

Soft skill training is given paramount importance to enhance employee development and sharp response high customer satisfaction. Besides the right domain knowledge, non-functional skills have immense importance in lieu of discharging their responsibilities. Over and above the product knowledge, employees are expected to have excellent telephone etiquette, which includes listening skills negotiation skills, grievance handling \&conversational ability, enthusiasm, energy, and so on [26].

\section{Induction and onboarding training}

Soon after the staff members are selected they are oriented about a basic framework like baking scenario, Polices, working conditions, expectation, macro-economic situations Pay scale, Career progression, and planning, to enable them to acclimatized to organization practices, culture[26].

\subsection{Training Interventions across banks are always graded and need-based}

Table 2. Mentions the below-mentioned training framework as per recommendaton of RBI

\begin{tabular}{|c|c|c|}
\hline Sl.No. & Category of employees & Type of Training or Intervention \\
\hline 1. & For newly recruited staff & $\begin{array}{l}\text { (OJT) On the Job Training, Mentorship, Job } \\
\text { Rotation, Compulsory Certification }\end{array}$ \\
\hline 2. & $\begin{array}{l}\text { For junior officers between having 2-5 Years of } \\
\text { work experience }\end{array}$ & Same as above \\
\hline 3. & $\begin{array}{l}\text { For middle level Officers having 5-15 years of } \\
\text { work experience }\end{array}$ & $\begin{array}{l}\text { Besides the above mentioned the other areas of } \\
\text { training are } \\
\text { allocating project assignments, } 360 \text {-degree } \\
\text { feedback system, Scrutiny by top leadership, } \\
\text { Nomination to Leadership Academies (Top } 500 \\
\text { future leaders) }\end{array}$ \\
\hline 4. & $\begin{array}{l}\text { For seniors officers and executive having work } \\
\text { experience of } 15 \text { years and more }\end{array}$ & $\begin{array}{l}\text { Leading Project teams for change management } \\
\text { projects, Through Leadership Scoreboards, } \\
\text { Scrutiny by Chief Executive, special and critical } \\
\text { assignments. }\end{array}$ \\
\hline 5. & Specialist Stream (Credit) & By posting in Credit Hubs and field methods \\
\hline 7. & Specialists in Treasury/Fund Management/Forex & $\begin{array}{l}\text { By Industry participation } \\
\text { On the Job Training, Special Certification } \\
\text { programs, Leadership Development Programs, } \\
\text { Field projects }\end{array}$ \\
\hline 8. & $\begin{array}{l}\text { Specialists in Technology } \\
\text { (IT Officers) }\end{array}$ & -----Same as above ------ \\
\hline 9. & $\begin{array}{l}\text { Specialists - Relationships/Client Management } \\
\text { Specialists - Operations/Channel Management } \\
\text { Specialists - Functional/Shared Services } \\
\text { Specialists - Product Development }\end{array}$ & $\begin{array}{l}\text { By Posting in different business verticals } \\
\text { Certifications }\end{array}$ \\
\hline
\end{tabular}

Source: Report of the Committee on Capacity Building in Banks and non-Banks published by RBI [24]

\subsection{Challenges of Banking Sector in India}

a. Employees' Retention - The competition to retain key employees is intense. Top level executives and HR departments spend large amounts of time, effort, and money trying to figure out how to keep their people from leaving owing to tremendous growth in completion and blanket of globalization [27]. 
b. Financial Inclusion- A challenge in itself to include all the citizens of the country under the ambit of formal banking is a herculean task as, awareness, educating, willingness to people of India especially the rural segment is questionable[27].

c. Customer Retention- Due to the competition and slew of measures by regulatory bodies and customer centric market, features like account portability if dissatisfied with the services of a bank. Customers have an upper hand and choice of many. Leaving the bankers only to grapple with the situation[27].

d. Rural Market - with $72 \%$ of Indians residing in villages ( as per census 2011) reaching to rural areas and remote villages to provide basic banking services is no less than a mammoth task, on the other hand, urban customers are shifting to digitalization and except for high end tech savvy services, hence two ends with a balanced approach is a difficult task[27].

e. General banking is obsolete: Gone are days of general banking especially amongst the cosmopolitan , Corporate ad urban customers, specialized and customized banking services is the order of the day, providing impeccable customization of multiple services is imperative to sustain[27].

\subsection{Analysis, Discussion \& Results}

Validity Test

Table 3.

\begin{tabular}{|c|c|}
\hline Cronbach's Alpha & N of Items \\
\hline .781 & 4 \\
\hline
\end{tabular}

\section{Realibity statistics}

From table 3, Realibility statistics, the value of Cronbach Alpha value is .781, hence data validity is acceptable. (Cronbach's Alpha value anything above .60 is acceptable)[15] .

H1: To understand the impact of soft skills training on employee development Table 4.

\begin{tabular}{|c|c|c|c|}
\hline R & R Square & Adjusted R Square & $\begin{array}{c}\text { Std. The error of the } \\
\text { Estimate }\end{array}$ \\
\hline $.508 \mathrm{a}$ & .258 & .232 & .22617 \\
\hline
\end{tabular}

a. Predictors: (Constant), Overall Training

b. Table 4 : Regression

Table 5.

\begin{tabular}{|c|c|c|c|}
\hline Model & Sum of Squares & df & Mean Square \\
\hline Regression & .498 & 1 & .498 \\
\hline Residual & 1.432 & 59 & \\
\hline Total & 1.931 & 60 & \\
\hline
\end{tabular}

a. Dependent Variable: Employee Development 
Table 6.

\begin{tabular}{|l|l|l|l|l|l|}
\hline Model & \multicolumn{2}{|l|}{$\begin{array}{l}\text { Unstandardized } \\
\text { Coefficients }\end{array}$} & $\begin{array}{l}\text { Standardized } \\
\text { Coefficients }\end{array}$ & Sig \\
\hline & B & $\begin{array}{l}\text { Std. } \\
\text { Error }\end{array}$ & Beta & & \\
\hline (Constant) & 1.710 & .762 & & 2.246 & .033 \\
\hline Overall Training & .603 & .193 & .508 & 3.121 & .004 \\
\hline & & & & & \\
\hline
\end{tabular}

\section{Interpretation}

A simple regression analysis was conducted to determine the relation between overall soft skill training and employee development in banks. This overall regression model produced an $\mathrm{R}^{2}$ of .25 which means that the overall soft skill training explained $25 \%$ of the variance in the dependent variable Employee development in banks. The overall model was significant, $\mathrm{F}(1,59)=9.741, \mathrm{p}<.05$ and it accounted for $25 \%$ of the variance. The results indicated that overall soft skill training in banks $(\beta=.508, \mathrm{p}<.05)$ was having a statistically significant and positive relationship with the ESSD. The strength of the relationship between the overall soft skill training $(\beta=.558)$ and Employee development was also found very high. (evident in table 4, 5, 6).

H2: The dimensions of soft skill training (training methodology \& trainer's ability) have a positive linear relationship with employee performance Interpretation

Table. 7

\begin{tabular}{|c|c|c|c|}
\hline R & R Square & Adjusted R Square & $\begin{array}{c}\text { Std. Error of the } \\
\text { Estimate }\end{array}$ \\
\hline $.599 \mathrm{a}$ & .359 & .311 & .25872 \\
\hline
\end{tabular}

Table 8.

\begin{tabular}{|c|c|c|c|c|c|}
\hline Model & $\begin{array}{c}\text { Sum of } \\
\text { Squares }\end{array}$ & df & $\begin{array}{c}\text { Mean } \\
\text { Square }\end{array}$ & F & Sig. \\
\hline Regression & 1.011 & 1 & .506 & 7.554 & $.002^{\mathrm{b}}$ \\
\hline Residual & 1.807 & 59 & .067 & & \\
\hline Total & 2.819 & 60 & & & \\
\hline
\end{tabular}

a. Dependent Variable: employee performance

b. Table 8: Anova

Table 9.

\begin{tabular}{|c|c|c|c|c|c|}
\hline Model & \multicolumn{2}{|c|}{$\begin{array}{c}\text { Unstandardized } \\
\text { Coefficients }\end{array}$} & $\begin{array}{c}\text { Standardized } \\
\text { Coefficients }\end{array}$ & t & Sig. \\
\hline & B & $\begin{array}{c}\text { Std. } \\
\text { Error }\end{array}$ & Beta & & \\
\hline (Constant) & 2.007 & .648 & & 3.095 & .005 \\
\hline TM_Mean & .549 & .145 & .606 & 3.780 & .001 \\
\hline TA_Mean & -.021 & .124 & -.028 & -.172 & .865 \\
\hline
\end{tabular}




\section{a. Dependent Variable: Employee performance}

\section{b. Table 9 : correlation coefficient}

A multiple regression analysis tests was conducted to determine the relation between the dimensions of soft skill training and employee performance in banks. This overall regression model produced an $\mathrm{R}^{2}$ of .35 which means that all dimensions of soft skill training explained $35 \%$ of the variance in the dependent variable employee performance in banks. The overall model was significant, $F(1,59)=7.554, \mathrm{p}<.05$ and it accounted for $35 \%$ of the variance. The results indicated that training methodology $(\beta=.606, p<.05)$ has a positive linear relationship with employee performance, whereas, trainers ability $(\beta=-.028, \mathrm{p}>.05)$ showed no significant relationship with employee performance in banks(evident in table 7, 8,9).

\section{H3: Soft Skill Training has an impact to bring positive behaviour}

Table 10.

\begin{tabular}{|c|c|c|c|}
\hline R & R Square & Adjusted R Square & $\begin{array}{c}\text { Std. Error of the } \\
\text { Estimate }\end{array}$ \\
\hline $.547 \mathrm{a}$ & .299 & .287 & .60148 \\
\hline
\end{tabular}

a. Predictors: (Constant), Training had the potential to bring positive change in my behaviour

b. Table 10 : Regression

Table 11.

\begin{tabular}{|c|c|c|c|c|c|}
\hline Model & $\begin{array}{c}\text { Sum of } \\
\text { Squares }\end{array}$ & df & Mean Square & F & Sig. \\
\hline Regression & 8.950 & 1 & 8.950 & 24.740 & $.000^{\mathrm{b}}$ \\
Residual & 20.983 & 58 & .362 & & \\
Total & 29.933 & 59 & & & \\
\hline
\end{tabular}

a. Dependent Variable: Performance has increased through reduced error and conflicts

c. Predictors: (Constant), Training had the potential to bring positive change in my behaviour

d. Table 11 : Anova

\section{Interpretation}

A linear regression analysis test was conducted to determine the relation between the dimensions of soft skill training and positive behaviour in the employee performance of banks. This overall regression model produced an $\mathrm{R}^{2}$ of .29 which means that the soft skill training explained $29 \%$ of the impact in the dependent variable positive behaviour in banks. The overall model was significant, $F(1,59)=24.7, p<.05$ and it accounted for $29 \%$ of the variance. The results indicated that Training potential (Significance value $0.000, \mathrm{p}<.05$ ) has a positive linear relationship with positive behaviour showed no significant relationship with increased employee performance in banks. (evident in table 10 and 11).

\subsection{Conclusion}

Research study revealed that soft skills training imparted to employees of banking employees had a positive and linear relationship with the development of their knowledge, skill, behavior, teamwork and personal development. It is clear that through statistical analysis that soft skill training acts a potential tool for development of employees, in turn, the performance of organizations (Banks in this context). This study illustrates that trained employees discharge their duties with diligence and increased knowledge. Hence training is an important and constructive intervention, it reinforces the performance of employees.

\subsection{Scope for further research}

- Employee performance is a quality and quantity dimension measured by referring to Key Performance Areas (KPA), Key Result Areas (KRA), and feedback sought by customers, which was not done in this research. The findings of research done on these parameters can act as suggestions/ areas for 
improvements for staff training colleges to modulate their training to cater to the actual training needs of employees.

- Researchers can further study the correlation ship between learning styles of employees and the method adopted for imparting soft skill training. To know if there is a proper synchronization between learning styles and methods used, this said research can provide insights to modulate training methods if needed because learning styles of individuals are inherent and very hard to change.

- $\quad$ Since the workforce in any organisation is a blend of people coming from diversified backgrounds, it may be ascertained, if background of the employees has an influence on the efficiency of the training programs conducted, opinion of the employees can be sought to know if there education and cultural backgrounds unable or enable them to acquire the information, knowledge, and skills imparted during the training program.

- A study on the impact of soft skill training on human relations at work can be taken up to ascertain if soft skills have the potential to promote harmony amongst coworkers and higher ups. This study can revolve parameters like a conflict with peers and higher ups, and promote self-control. In other words, this research study can be done to know whether soft skills training promotes and influences imbibing social skills.

- It will be interesting to conduct a comparative study to know formal vis a vis informal ways of learning/ acquiring soft skills by employees/ Trainees. Formal ways of learning include learning through classroom training, outbound training, staff development program, Informal ways of learning include learning by watching online videos, reading books, through this research, it may be ascertained which of the methods/ techniques are more efficient in imparting soft skills training.

\subsection{Acknowledgement}

This research was conducted on the employees of branches of the banks in the city of Belagavi, Karnataka. Banks considered for the study include Axis Bank and HFDC, Union Bank of India, IDBI, Corporation Bank, Canara Bank.

\section{Annexure}

\section{Respected Respondent,}

This questionnaire is designed to for a research study titled "A study on soft skill training as an intervention to reinforce employee performance in the contemporary banking sector " I Prof Sanjay K Deshpande, Research Scholar at VTU, RRC, Belagavi request you to respond to the questions frankly and honestly. Your response will be kept strictly confidential and is meant to be used only for the purpose of academic research. Thank you in advance for your time and cooperation. I greatly appreciate you and your organization in the context of this research endeavor.

\section{Section A. About training}

\begin{tabular}{|c|c|c|c|c|}
\hline 5 & 4 & 3 & 2 & 1 \\
Excellent & Good & $\begin{array}{c}\text { Neither good nor } \\
\text { bad }\end{array}$ & Poor \\
\hline
\end{tabular}

Write the number in the box space provided next to each question based on your satisfaction level:

1. Venue and arrangements for the training were

2. Contents of training were suited to my level of knowledge and skills. 
3. Methods, games, activities used in the training were

4. Time allocated for the training was

5. Relationship of activities with real working scenarios

6. Morale and understand of each activity was

7. The extent to which training was able to fulfil expectations

Section B. About the INSTRUCTORs / Facilitators/ Trainers:

\begin{tabular}{|c|c|c|c|c|}
\hline 5 & 4 & 3 & 2 & 1 \\
Strongly agree & Agree & $\begin{array}{c}\text { Neither good } \\
\text { nor bad }\end{array}$ & Disagree & $\begin{array}{c}\text { Strongly } \\
\text { Disagree }\end{array}$ \\
\hline
\end{tabular}

Write the number in the box space provided next to each question based on your satisfaction level:

1. Trainers demonstrated knowledge of the subject with confidence

2. Trainers were clear and understandable.

3. Trainers were able to motivate participation.

4. Adjusted the pace of the training.

5. Trainers were able to relate the activities to real life situations

6. Trainers demonstrated knowledge of the subject with confidence 


\section{Impact evaluation}

\begin{tabular}{|c|c|c|c|c|}
\hline $\begin{array}{c}5 \\
\begin{array}{l}\text { Strongly } \\
\text { agree }\end{array}\end{array}$ & Agree & $\begin{array}{c}3 \\
\text { Neither } \\
\text { good nor bad }\end{array}$ & Disagree & Strongly Disagree \\
\hline
\end{tabular}

Write the number in the box space provided next to each question based on your satisfaction level:

\begin{tabular}{|l|l|}
\hline 1. Knowledge and skills have increased & \\
\hline 2. felt the contents of training had the potential to shape my personality & \\
\hline 3. Though training I understood expectations and could work with clarity & \\
\hline 4. Training had the potential to bring positive change in my behaviour & \\
\hline 5. Was able to know the ways of working with a team & \\
\hline 6. Knowledge and skills have increased & \\
\hline
\end{tabular}




\section{References}

[1] Heckman, J. J., \& Kautz, T. Hard evidence on soft skills. Labour Economics, 19(4), 451-464. 2012

[2] Report of the commitee on capacity buikding in banks and non banks. (2018, August). [3] Ministry of Commerce \& Industry, G. 0. Banking Sector in India. 2018, August 06 Monday

[4] http://journal.sbm.itb.ac.id/ 2018

[5] Saraiya, R.G. Report of the Banking Commission, op. cit., p. 35

[6] Hundekar, V. R. (2017). Financial Inclusion in India. GBS IMPACT: Journal of Multi Disciplinary Research,3(1), 7-10.

[7] Human Resource and Skill Requirements in the Banking Financial Services \& Insurance Sector(2022) a report. (n.d.). August 2018

[8] Consumer protection in the banking sector (publication). (n.d.). mumbai: rbi.2018

[9] Rolf Lyton, U. Pareek. (2009). Training for Organizational Transformation. New Delhi: Sage Publication

[10] Deshpande, S. K., \& Munshi, M. M. (2014). An empirical study on "The Impact of outbound training (OBT) on personality and behaviour of Management students. IUP Journal of Soft Skills, 3, 56-65.

[11] Bughin, J., Hazan, E., Lund, S., Dahlström, P., \& Wiesinger, A. Mckinsey global institute skill shift automation and the future of the workforce (rep) 2018

[12] Mehta, K., Bandyopadhyay, A., \& Shah, M. (n.d.). Banking on the Future: Vision 2020(Rep.), 2018

[13] CONARC Soft Skills Training Conference. (n.d.), 340.

[14] Rosemary, Harrison, "Learning and Development", Chartered Institute of Personnel and Development, London, P. 5, 2005.

[15] The role of soft skills in employability. International journal of management research and review, 2(7), 1285-1292. (2012).

[16] Ikramina, F., \& Gustomo, A. Analysis of the training evaluation process using Kirkpatrick's training evaluation model at pt. bank tabungan negara. Journal of business and management, 3(1) 102-111 2014

[17] Deshpande, S. K., \& Munshi, M. M. A Study on Comparative Analysis of Impact of Soft Skill Training on the Employees of Private and Public Sector Banks in the City of Belgaum, Karnataka. International Journal of Economics \& Management Sciences, 6(6). 2017.

[18] Ibrahim, R., Boerhannoeddin, A., \& Bakare, K. K. The effect of soft skills and training methodology on employee performance. European Journal of Training \& Development, 41(4), 388-406.2017.

[19] Reserve Bank of India - Speeches. (n.d.). Retrieved November 20, 2018.

[20] Charoensap-Kelly, P., Broussard, L., Lindsly, M., \& Troy, M. Evaluation of a Soft Skills Training Program. Business and Professional Communication Quarterly, 79(2), 154 179.2016.

[21] Amitabh Deo Kodwani, "Decoding training effectiveness: the role of organizational factors", Journal of Workplace Learning, Vol. 29 Issue: 3. 2017 
[22] Omar, alicia, salessi, solana, \& urteaga, florencia. . Impact of management practices on job satisfaction. Ram. Revista de administração mackenzie, 18(5), 92-115. 2017

[23] Bhagra, A., \& Sharma, D. K. Changing paradigm of employability skills in the global business world: A review. IUP Journal of Soft Skills, 12(2), 7-24. 2018

[24] Krishna, G. Committee on capacity building report and recommendations (rep.). mumbai: rbi.2014

[25] Clarence Dillon. (n.d.). Retrieved February 7, 2019

[26] Pandey, A. Innovative Training Solutions For Banking And Financial Services. 2015

[27] Indian Banking Industry: Challenges and Opportunities. (n.d.). Retrieved February 7, 2019 